Gynäk. Rdsch. 1982;22(Suppl. 2):I-IV

\title{
Contents, Vol. 22, Supplement 2, 1982
}

\section{Inhalt}

Vorwort

1

Editorial

Epidemiologie und Klinik der Trichomoniasis (Epidemiology and

Clinic of Trichomoniasis)

Rüttgers, $\mathrm{H} \quad 3$

Über den Ansteckungsmechanismus, die Rezidive und die

Reinfektion bei Trichomoniasis vaginalis beim Menschen

(Trichomoniasis: Mechanism of Infection, Recurrences and

Reinfections in Man)

Bedoya,J.M 10

Diagnostische Probleme (Diagnostic Problems)

Jenny, J.W 16

Konventionelle Therapie der Trichomoniasis (Conventional Therapy

of Trichomoniasis)

Richter, R 23

Vakzination mit SolcoTrichovac. Immunologische Aspekte eines

neuen Prinzips zur Therapie und Reinfektionsprophylaxe der

Trichomoniasis bei der Frau (Vaccination with SolcoTrichovac.

Immunological Aspects of a New Aproach for Therapy and

Prophylaxis of Trichomoniasis in Women)

Pavic, R.; Stojkovic, L

Serologische Untersuchungen mit SolcoTrichovac, einer Vakzine

gegen die Trichomonas-vaginalis-lntektion bei der Frau

(Serological Studies with SolcoTrichovac, a Vaccine against

Trichomonas vaginalis Infection in Women)

Milovänovic, R.; Grcic, R.; Stojkovic, L

IgA-Antikörper im Vaginalsekret nach der Impfung mit

SolcoTrichovac (IgA Antibodies in the Vaginal Secretion after

Vaccination with SolcoTrichovac)

Milovänovic, R.; Grcic, R.; Stojkovic, L 46

Inhalt

IV

Veränderungen der vaginalen Flora von Trichomoniasispatientinnen

durch die Vakzination mit SolcoTrichovac (Changes in the

Vaginal Flora in Patients with Trichomoniasis after Vaccination

with SolcoTrichovac)

Milovanovic, R.; Grcic, R.; Stojkovic, L 
Einfluss der Impfung mit SolcoTrichovac auf die Vaginalflora und die Morphologie der Döderlein-Bazillen (Influence of Vaccination with SolcoTrichovac on the Vaginal Flora and the Morphology of the Doederlein Bacillus)

Goisis, M.; Magliano, E.; Goisis, F 55

Klinische Erfahrungen mit SolcoTrichovac bei der Behandlung der

Trichomonadeninfektion der Frau (Clinical Experience with

SolcoTrichovac in the Treatment of Trichomonas Infection in

Women)

Lorenz, U.; Rüttgers, $\mathrm{H}$

Randomisierte Doppelblindstudie über die Reinfektionsprophylaxe

von Trichomoniasis durch die Impfung mit SolcoTrichovac

(SolcoTrichovac in the Prophylaxis of Trichomonad Reinfection.

A Randomized Double-Blind Study)

Litschgi, M 70

SolcoTrichovac in der Praxis. Eine offene, multizentrische Feldstudie zur Pruning des antitrichomonalen Impfstoffes SolcoTrichovac

(SolcoTrichovac in Practice. An Open, Multicentre Study to

Investigate the Antitrichomonal Vaccine SolcoTrichovac)

Rippmann, E.T

74

Therapeutische und prophylaktische Wirkung von SolcoTrichovac bei Frauen mit Trichomoniasis. Eine Untersuchung in Kairo

(Therapeutic and Prophylactic Effect of SolcoTrichovac against

Trichomoniasis in Women. Investigations in Cairo)

Elokda, H.H.; Andrial, M 81

Autorenregister Sachregister . .

8586 